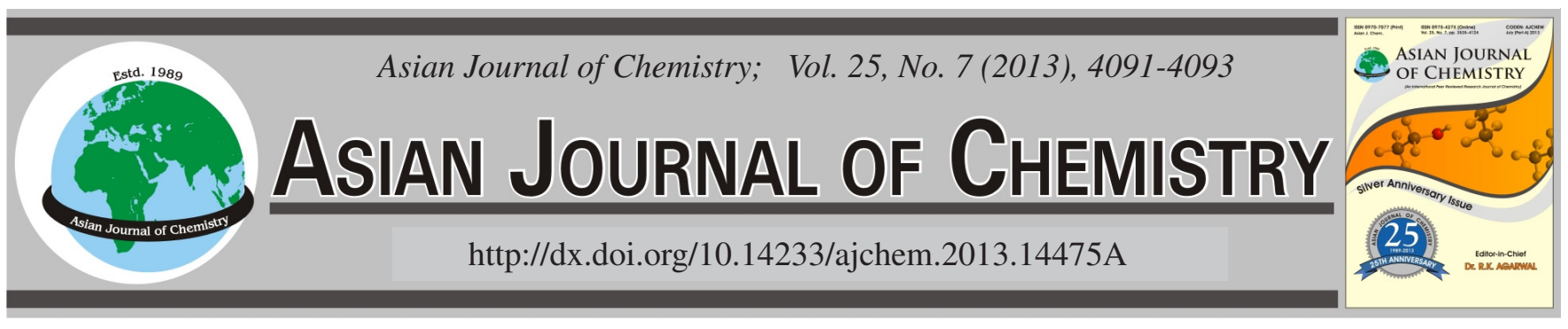

\title{
Colour Reaction of Dibromo-p-chloro-chlorophosphonazo with Magnesium(II) and Analytical Application
}

\author{
Qing-ShuAng WANG and Qing-Zhou Zhai
}

Research Center for Nanotechnology, South Campus, Changchun University of Science and Technology, 7186 Weixing Road, Changchun 130022, P.R. China

*Corresponding author: E-mail: zhaiqingzhou@163.com

(Received: 24 August 2012;

\begin{abstract}
Using a complex colour reaction of DBC-chlorophosphonazo with magnesium(II), a spectrophotometric method for the determination of magnesium(II) has been developed. The apparent molar absorptivity of method is $\varepsilon_{620 \mathrm{~mm}}=2.03 \times 10^{4} \mathrm{~L} \cdot \mathrm{mol}^{-1} \cdot \mathrm{cm}^{-1}$. Beer's law is followed over the range of $0-1.2 \mu \mathrm{g} / \mathrm{mL}$ for magnesium(II). Its regression equation is: $\mathrm{A}=0.1604 \mathrm{C}(\mathrm{C}: \mu \mathrm{g} / \mathrm{mL})+0.0079$, with a correlation coefficient of $r=0.9993$. The method has been satisfactorily applied to the determination of magnesium(II) in tobacco samples.
\end{abstract}

Key Words: Magnesium, DBC-Chlorophosphonazo, Colour reaction, Tobacco.

\section{INTRODUCTION}

Magnsium(II) is a necessary important nutrition element for human body and participates in many kinds of metabolisms. The lack of magnesium can result in arrhythmia and cardiac failure ${ }^{1}$. Magnesium plays an important role in blood sugar stabilization and the biological activity aspect of trypsin ${ }^{2}$. As acquaintanceship of the importance of magnesium deepens,studies of the determination methods for magnesium are also impelled. The determination method for macro magnesium adopts titration method ${ }^{3}$. The determination methods for micro and trace amount of magnesium have atomic absorption spectrometry ${ }^{4}$, fluorescence method ${ }^{5}$, etc. However, they have the disadvantages of instrumentation valuableness and operation complexity, etc. Spectrophotometry has the advantages of operation simplicity and instrumentation cheapness, etc. and determination of magnesium has higher practicability. At present, Congo red 6 , 4-(2-hydorxyl-4-nitrophenylazo)-1-phenyl-3-methyl-pyrazolone ${ }^{7}$, arsenazo-III ${ }^{8}$, chlorophosphonazo$\mathrm{I}^{9}$ spectrophotometric methods for the determination of magnesium have been proposed. However, the selectivity of this kind of method is still very poor. Therefore, development of novel spectrophotometric method for the determination of magnesium has an important significance. Dibromo- $p$-chlorochlorophosphonazo (abbreviated as: DBC-CPA) (Fig. 1).

Dibromo- $p$-chloro-chlorophosphonazo has been applied to spectrophotometric determination of rare earths ${ }^{10}$ and copper $^{11}$. This paper established a method for the spectrophotometric determination of magnesium. The operation of method

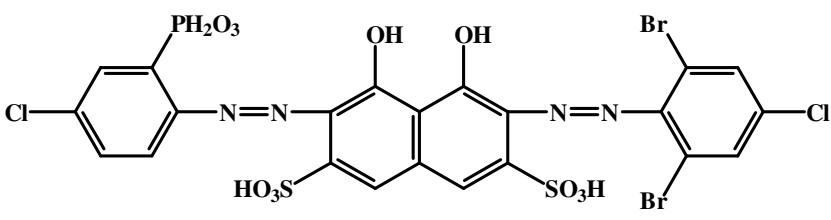

Fig. 1. Molecular structure of DBC-CPA (m.f. $\mathrm{C}_{22} \mathrm{H}_{13} \mathrm{~N}_{4} \mathrm{O}_{11} \mathrm{PS}_{2} \mathrm{Br}_{2} \mathrm{Cl}_{2}$ )

is simple and fast. It has been successfully applied to the determination of magnesium in tobacco samples.

\section{EXPERIMENTAL}

A 722 spectrophotometer (Shanghai Prism Light Technology Corporation, Ltd., China) with $1 \mathrm{~cm}$ cells was used for all absorbance measurements in this work. $5.9 \times 10^{-4} \mathrm{~mol} / \mathrm{L}$ of dibromo- $p$-chloro-chlorophosphonazo (DBC-CPA, Shanghai Jinsheng Chemical Corporation, Ltd., China) solution was used as chromogenic agent solution. Standard stock solution (1 mg/ $\mathrm{mL}$ ) of $\mathrm{Mg}^{2+}$ was prepared by dissolving $0.1658 \mathrm{~g}$ magnesium oxide in $1 \mathrm{~mL}$ of concentrated hydrochloric acid and the content was diluted to $100 \mathrm{~mL}$. The working solution $(2 \mu \mathrm{g} /$ $\mathrm{mL}$ ) was prepared by the suitable dilution of the stock solution. $\mathrm{pH} 10.2 \mathrm{NH}_{3}-\mathrm{NH}_{4} \mathrm{Cl}$ buffer solution was used to control the acidity of colour reaction. All chemicals used were of analytical pure grade and distilled water was used throughout this work.

$6 \mu \mathrm{g}$ of magnesium(II) working solution was taken and placed in $10 \mathrm{~mL}$ calibrated flask, $1 \mathrm{~mL}$ of $5.9 \times 10^{-4} \mathrm{~mol} / \mathrm{L}$ DBC-CPA solution and $1 \mathrm{~mL}$ of $\mathrm{pH} 10.2 \mathrm{NH}_{3}-\mathrm{NH}_{4} \mathrm{Cl}$ buffer solution were added. The above solution was diluted with water 
to the mark and shaken. After $10 \mathrm{~min}$,the absorbance was determined at $620 \mathrm{~nm}$ with $1 \mathrm{~cm}$ cells using reagent blank as reference.

\section{RESULTS AND DISCUSSION}

Absorption spectra: Absorption spectra are shown as Fig. 2. The maximum absorption wavelength of complex is located at $620 \mathrm{~nm}$ and the maximum absorption wavelength of reagent blank is located at $580 \mathrm{~nm}$. In the work, $620 \mathrm{~nm}$ was selected as the determination wavelength.

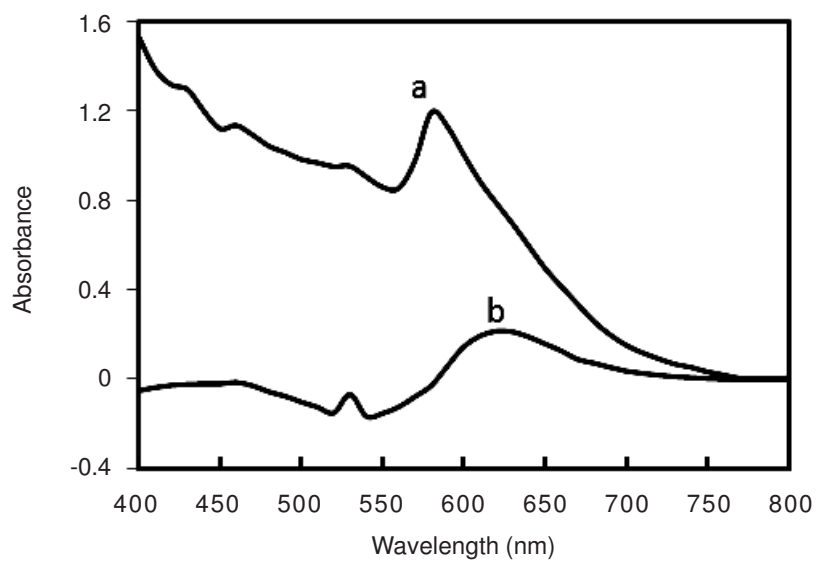

Fig. 2. Absorption spectra: (a) DBC-CPA (against water); (b) complex (against reagent blank); $\left[\mathrm{Mg}^{2+}\right]=2.5 \times 10^{-5} \mathrm{~mol} / \mathrm{L} ;[\mathrm{DBC}-\mathrm{CPA}]=$ $5.9 \times 10^{-5} \mathrm{~mol} / \mathrm{L} ; \mathrm{pH}=10.2$

\section{Optimum experimental conditions}

Effects of acidity: According to the standard procedure, the effect of different $\mathrm{pH}$ condition on reaction system was respectively examined. The experimental results showed that the absorbance of complex increased as $\mathrm{pH}$ increased over the range of 8.0-10.0. When $\mathrm{pH}$ was within $\mathrm{pH} 10.0-10.5$, the absorbance of complex was maximum and smooth. The absorbance of complex decreased as $\mathrm{pH}$ increased within $\mathrm{pH}$ 10.512.0. Thus, in this work $\mathrm{pH}=10.2 \mathrm{NH}_{3}-\mathrm{NH}_{4} \mathrm{Cl}$ buffer solution was chosen as the reaction medium. The effect of buffer solution amount was not great. Within $0.5-2.0 \mathrm{~mL}$, the absorbance was basically unchangeable. At $1.0 \mathrm{~mL}$, the absorbance was a maximum. In this experiment $1.0 \mathrm{~mL}$ was chosen.

Effect of the amount of DBC-CPA: The experimental results showed that when the added amount of CPApA was 0-1.0 mL, the absorbance of complex increased as the amount of colour agent increased. At $1.0 \mathrm{~mL}$, the absorbance attained a maximum. Within 1.0-2.0 mL, the absorbance decreased with increase in the amount of colour agent. Therefore, $1.0 \mathrm{~mL}$ of $5.9 \times 10^{-4} \mathrm{~mol} \cdot \mathrm{L}^{-1} \mathrm{DBC}-\mathrm{CPA}$ solution was selected. At this time, $[\mathrm{DBC}-\mathrm{CPA}]=5.9 \times 10^{-5} \mathrm{~mol} / \mathrm{L}$.

Effect of surfactant: According to the standard procedure, the effect experiments of cetyltrimethylammonium bromide, OP-100 and sodium lauryl sulfate were respectively made. The results showed that the all above three kinds of different type surfactants made the sensitivity of colour reaction reduce.

Effect of temperature: The experiment showed that the complex absorbance became larger as the temperature increased over the range of $2-20{ }^{\circ} \mathrm{C}$. Over the range of 20-
$50{ }^{\circ} \mathrm{C}$, the absorbance attained maximum. Over the range of $50-100{ }^{\circ} \mathrm{C}$, the complex absorbance decreased as the temperature increased. Therefore, the study was made at room temperature $\left(22 \pm 2{ }^{\circ} \mathrm{C}\right)$.

Complex stability and composition: The experimental results showed that DBC-CPA and $\mathrm{Mg}$ (II) produced a complex within $10 \mathrm{~min}$. The complex retained stable within $2 \mathrm{~h}$ and the variation of absorbance was less than $5 \%$. The complex molar ratio of DBC-CPA with $\mathrm{Mg}$ (II) in the complex, determined by molar ratio method and equimolar continuous variation method, was 1:1.

Working curve: The experimental results showed that Beer's law is obeyed over the range of $0-1.2 \mu \mathrm{g} / \mathrm{mL}$ for $\mathrm{Mg}(\mathrm{II})$, its apparent molar absorptivity is $\varepsilon_{620 \mathrm{~nm}}=2.03 \times 10^{4} \mathrm{~L} \mathrm{~mol}^{-1}$ $\mathrm{cm}^{-1}$ and regression equation is $\mathrm{A}=0.1604 \mathrm{C}(\mathrm{C}: \mu \mathrm{g} / \mathrm{mL})+$ 0.0079 , with a correlation coefficient of $\mathrm{r}=0.9993$. For eleven parallel determinations of $0.6 \mu \mathrm{g} / \mathrm{mL} \mathrm{Mg}$ (II), the relative standard deviation of method was calculated to be $1.11 \%$. For eleven parallel determinations of reagent blank, the detection limit of method was calculated to be $8.92 \mathrm{ng} / \mathrm{mL}$ according to $3 \mathrm{~S} / \mathrm{K}$ method ( $\mathrm{S}$ is the standard deviation of eleven blank experiments, $\mathrm{K}$ is the slope of regression equation).

Effect of co-existing ions: When $0.6 \mu \mathrm{g} / \mathrm{mL}$ of $\mathrm{Mg}$ (II) was determined and relative error was controlled within $\pm 5 \%$, the following amounts $(\mathrm{m} / \mathrm{m})$ of co-existing ions did not cause interferences: $\mathrm{SiO}_{3}{ }^{2-}, \mathrm{F}^{-}$(130); $\mathrm{SO}_{4}{ }^{2-}$ (120); $\mathrm{NO}_{2}^{-}$(40); $\mathrm{NO}_{3}{ }^{-}$, $\mathrm{Br}^{-}, \mathrm{BrO}_{3}^{-}$(60); $\mathrm{MoO}_{4}{ }^{2-}(30) ; \mathrm{PO}_{4}{ }^{3-}(15) ; \mathrm{S}_{2} \mathrm{O}_{7}{ }^{2-}$ (10); $\mathrm{Zn}^{2+}$, $\mathrm{Pb}^{2+}, \mathrm{Co}^{2+}, \mathrm{Mn}^{2+}, \mathrm{Ag}^{+}(5)$; $\mathrm{Cr}(\mathrm{VI}), \mathrm{Bi}^{3+}, \mathrm{Fe}^{2+}, \mathrm{Ni}^{2+}, \mathrm{Cu}^{2+}, \mathrm{Ba}^{2+}$, $\mathrm{Li}^{+}, \mathrm{MnO}_{4}^{-}, \mathrm{VO}_{3}^{-}, \mathrm{I}^{-}(2) ; \mathrm{Fe}^{3+}\left(1,8^{\mathrm{a}}\right), \mathrm{Al}^{3+}\left(2,8^{\mathrm{a}}\right) ; \mathrm{Cr}^{3+}(1) ; \mathrm{Ca}^{2+}$ $\left(0.1,0.5^{\mathrm{a}}\right)\left(\mathrm{a}: 2.0 \mathrm{mg}\right.$ of EDTA-Na $\mathrm{Na}_{2}$ were added).

Analytical application: $0.2 \mathrm{~g}$ of tobacco leaf were accurately weighed and placed in a beaker. $5 \mathrm{~mL}$ of concentrated hydrogen peroxide and $2 \mathrm{~mL}$ of concentrated nitric acid were added, the content was digested at low temperature and evaporated to near dryness. After the leftover substance was dissolved by $10 \mathrm{~mL}$ of $0.1 \mathrm{~mol} / \mathrm{L}$ hydrochloric acid, it was diluted to $100 \mathrm{~mL}$ with water as test solution. A suitable test solution was taken and the remainder was the same as the standard procedure for the determination of magnesium. Magnesium content in the samples was calculated and the determined results are seen in Table-1. It can be seen from the table that the results determined by the present method accorded with those by atomic absorption spectrometry. The recovery of method was between 98.71-101.1\%. The analytical results were satisfactory.

TABLE-1

ANALYTICAL RESULTS OF SAMPLE

\begin{tabular}{ccccc}
\hline Sample & $\begin{array}{c}\text { Found } \\
(\mathrm{n}=9, \%)\end{array}$ & $\begin{array}{c}\text { Relative } \\
\text { standard } \\
\text { deviation } \\
(\%)\end{array}$ & $\begin{array}{c}\text { Recovery } \\
(\%)\end{array}$ & $\begin{array}{c}\text { Atomic absorption } \\
\text { spectrometric } \\
\text { contrast method } \\
(\%)\end{array}$ \\
\hline No. 1 & 1.54 & 1.91 & 98.71 & 1.55 \\
No. 2 & 1.93 & 1.53 & 101.1 & 1.93 \\
\hline
\end{tabular}

In conclusion, the optimum colour reaction conditions for the determination of magnesium(II) with DBC-chlorophosphonazo have been established. At the maximum absorption peak $620 \mathrm{~nm}$ of complex, the apparent molar absorptivity 
of method is $2.03 \times 10^{4} \mathrm{~L} \cdot \mathrm{mol}^{-1} \cdot \mathrm{cm}^{-1}$. Beer's law is obeyed over the range of $0-1.2 \mu \mathrm{g} / \mathrm{mL}$ for magnesium(II) amount and its regression equation is: $\mathrm{A}=0.1604 \mathrm{C}(\mathrm{C}: \mu \mathrm{g} / \mathrm{mL})+0.0079$, with a correlation coefficient of $r=0.9993$. The magnesium in tobaccos have been successfully determined by the present method with satisfactory results.

\section{REFERENCES}

1. Q. Huang, H. Liang and F.P. Du, Stud. Trace Elements Health, 22, 61 (2005).

2. Y.T. Gao and A.P. Yin, Guangdong Trace Elements Sci., 10, 20 (2003).

3. F. Lian, Sichuan Nonferrous Metals, 2, 33 (2010).
4. J.Y. Yin, Z.Y. Liu and Z.J. Gao, Guangdong Trace Elements Sci., 16, 30 (2009).

5. S.B. Qiao, C.M. Jiao and Q.D. Wang, PTCA (Part B: Chem. Anal.), 45, 719 (2009).

6. X.B. Ma, L.P. Zhang and T. Liu, Fujian Anal. Test., 17, 15 (2008).

7. D.L. Li, Q.B. Huang, M. Li, H.T. Li, J.Y. Yin and Q.F. Hu, Arid Environ. Monit., 18, 5 (2004).

8. H.J. Liu, J. Jinzhou Normal Coll. (Nat. Sci. Ed.), 21, 48 (2000).

9. J.H. Wang, F. Ma, W.X. Su and Y.P. Liang, Shandong Metallurgy, 29, 50 (2007).

10. J.M. Pan, Z.J. Li, Q.Y. Zhang and G.Z. Fang, New Chromogenic Reagents and Their Application in Spectrophotometry, Beijing:Chemical Industry Press, p. 35 (2003).

11. Q.Z.Zhai and X.X. Zhang, PTCA (Part B: Chem. Anal.), 43, 114 (2007). 